\title{
Modeling and Practice of Erosion and Sediment Transport under Change
}

\author{
Hafzullah Aksoy ${ }^{1, *}$ (D) Gil Mahe ${ }^{2}$ and Mohamed Meddi ${ }^{3}$ \\ 1 Department of Civil Engineering, Istanbul Technical University, 34469 Istanbul, Turkey \\ 2 IRD, UMR HSM IRD/ CNRS/ University Montpellier, Place E. Bataillon, 34095 Montpellier, France \\ 3 Ecole Nationale Supérieure d'Hydraulique, LGEE, Blida 9000, Algeria \\ * Correspondence: haksoy@itu.edu.tr
}

Received: 27 May 2019; Accepted: 9 August 2019; Published: 12 August 2019

\begin{abstract}
Climate and anthropogenic changes impact on the erosion and sediment transport processes in rivers. Rainfall variability and, in many places, the increase of rainfall intensity have a direct impact on rainfall erosivity. Increasing changes in demography have led to the acceleration of land cover changes from natural areas to cultivated areas, and then from degraded areas to desertification. Such areas, under the effect of anthropogenic activities, are more sensitive to erosion, and are therefore prone to erosion. On the other hand, with an increase in the number of dams in watersheds, a great portion of sediment fluxes is trapped in the reservoirs, which do not reach the sea in the same amount nor at the same quality, and thus have consequences for coastal geomorphodynamics. The Special Issue "Modeling and Practice of Erosion and Sediment Transport under Change" is focused on a number of keywords: erosion and sediment transport, model and practice, and change. The keywords are briefly discussed with respect to the relevant literature. The papers in this Special Issue address observations and models based on laboratory and field data, allowing researchers to make use of such resources in practice under changing conditions.
\end{abstract}

Keywords: Anthropocene; climate change; deposition; erosion; modeling; practice; sedimentation; sediment transport; watershed

\section{Keywords of the Special Issue}

This Special Issue entitled Modeling and Practice of Erosion and Sediment Transport under Change is focused on five keywords. Two out of the five keywords are related to processes, which are erosion and sediment transport. Sediment particles are first detached from their original location by erosion under the effect of different agents, such as wind, rainfall, and runoff, followed by transportation. Another two keywords are the modeling and practice, which are mutually linked and both based on one other. Good practice is possible without a theoretically well-established model nor is modeling valuable when it is not applicable to practice. Finally, the crucial keyword, change, comes in the title of the Special Issue and serves as a kind of mirror to the future of the previous four keywords. Erosion and sediment processes should be modeled and practiced considering the hydrological conditions under continuous change. The keyword change is the most challenging and unclear of the Special Issue as it is born not only of natural reasons but also as a result of anthropogenic disturbances.

\section{Erosion and Sediment Transport}

Erosion is the process of detachment and transportation of soil materials by erosive agents [1] such as wind, rainfall, or runoff. In cold regions, snowmelt can cause significant erosion due to freshet and ice jams during the period of spring break-up [2-5]. Earthy or rock materials are loosened or dissolved, and they are removed from any part of the Earth's surface by erosion [6]. Erosion is a very important 
natural phenomenon that ends in soil loss. It causes also storage volume loss in river reservoirs where eroded sediment deposits. Water erosion is affected by the climate, topography, soil, vegetation, and anthropogenic activities such as tillage systems and soil conservation measures [7]. Land use and land cover characteristics are also important in the erosion process [8].

Four different processes that accomplish sediment removal and transport are the detachment by raindrop impact and runoff, and transport by raindrop splash and runoff. Flow and raindrop detachment rates are not simple and are, therefore, given by empirical formulas [9]. Once eroded, sediment is transported. Sediment particles have become detached are transported within flow as long as sediment load in the flow is smaller than its sediment transport capacity. The shear stress exerted by flow should also be greater than the critical value such that sediment particles are removed from their current locations. Otherwise, deposition takes place, which is the actual rate of mass temporarily reaching the overland surface. Deposition might exceed soil entrainment, which is called the net deposition; the opposite case is called net erosion, where the entrainment is higher than deposition. In the case of an equality of entrainment with sedimentation, equilibrium is reached in terms of erosion [10]. Sediment transport is influenced not only by hydraulic properties of flow but also by the physical properties of soil and surface characteristics.

\section{Modeling and Practice}

There are numerous methods are available in the literature for quantifying sediment transport over watersheds or in streams. The usual practice is to analyze the streamflow and sediment discharge time series statistically $[11,12]$ and to correlate the available streamflow and sediment discharge data $[13,14]$. Empirical approaches [15] are also frequently used in practice. Statistical analysis and stochastic modeling techniques have always been attractive alternatives because the monitoring and sampling are not easy tasks and, in most cases, the simultaneous streamflow and sediment discharge records are not available for comparatively long periods to enable conclusive deterministic relationships between sediment concentration and streamflow discharge. Therefore, time series models [16], in particular, were found to be useful in dealing with sediment transport problems. Among the many available studies, a number [17-20] are based on the time series modeling technique. However, traditional equations [21] as well as soft computational techniques [22] have also received great attention. In the meantime, monitoring, sampling, and surveying [23] as well as remote sensing and the use of geographical information systems [24] have continued to be important in sediment transport modeling.

As far as modeling is concerned, the Universal Soil Loss Equation (USLE) was designed as a tool to be used in the management practices of agricultural lands. It is one of the earliest attempts to compute the sediment yield in a catchment. Its development is based on data from the United States though it has subsequently been widely used all over the world. The USLE, along with some modifications and revisions (MUSLE and RUSLE), is still a useful tool in watershed management. A large number of the existing erosion and sediment transport models are based on the USLE. Their applications are, however, limited to the environmental circumstances from which the USLE was generated. The WEPP model in the United States and the SHESED and EUROSEM models in Europe were derived based on physical description of the erosion and sediment transport processes. Although preparation of data for physically based models is a hard task, they have been extensively used. It is obvious that a physically based model has much more detail than either USLE or its derivatives. Therefore, there has been a great effort towards developing physically based erosion and sediment transport models.

Due to their importance, hydrological models accommodate erosion and sediment transport modules in which the movement of sediment - that has been eroded by wind, rainfall, or flow, and transported-through the existing river channel to the reservoir is predicted. The SHESED [25], WEPP [26], SWAT [27], and WEHY [28,29] models are some of the well-known examples.

Erosion and sediment transport models are extensions of hydrological models. Therefore, erosion and sediment transport equations are coupled to existing hydrological algorithms. In such a coupling, 
the output of the hydrological model becomes the input for the erosion part of the model. In the same sense, an erosion and sediment transport model can be easily extended to a nutrient transport model, as it is known that nutrients are mainly transported by sediment particles. It is much easier to extend a multi-size erosion and sediment transport model to a nutrient transport model since nutrient transport is a size-selective process. For an extensive review on erosion and sediment transport, please refer to $[30,31]$.

\section{Climatological and Anthropogenic Changes}

The world's climate exhibits natural and unnatural variations and changes, with time scales ranging from millions of years down to one or two years. Over periods of several years, fluctuations of a few tenths of a degree in surface air temperatures over continents are common. These changes are related to global, regional, and even local scale events. Not only the climatological changes but also anthropogenic activities that could be superimposed on this varied hydrometeorological basis affect a wide variety of water use and management approaches. The individual components of the hydrological cycle are affected by the change. They might cause hydrological extremes such as droughts and floods, which are environmental issues turning back as direct consequences of natural or anthropogenic changes. Similarly, erosion and sediment transport over hydrological watersheds are heavily affected by such changes. Any change in either of the components of the hydrological cycle affects the hydrological behavior of the watershed and, thus, the erosion and sediment transport from the watershed surface.

A particularly important issue linked to the change in hydrology could be linked to stochastic modeling, which is based on the assumption that the time series is stationary. Generated sequences of any hydrological process under investigation, sediment discharge for instance, are considered stationary; i.e., they have the same statistical characteristics as the observed sequence. On the one hand, the stationarity is considered dead [32] with the change in hydrological processes [33-36]. On the other hand, however, it is still alive and inevitably useful in modeling hydrological processes [37-40] because it is convenient to use for making reliable predictions in engineering design. Also, the modeling concept based on the observed data is a useful practice due to the fact that the past is representative of the future [40]. Yet, any gradual and sudden changes due either to natural variation of the process under investigation or to any anthropogenic intervention should not be ignored. Such changes that could arise in the form of either a trend or a jump could be considered through the existing trend detection mechanisms and segmentation tools [41-44] to eliminate the nonstationarity of the process. Any jump or trend, when they exist, are determined and added into the modeled hydrological variables such that the nonstationary behavior of the process is taken into account.

\section{Summary of the Special Issue}

Eleven papers have been published in the Special Issue among a much larger collection of submissions. The published papers deal with different aspects of erosion and sediment transport by using different methodologies, through different practices, implementing different scale datasets, collecting in situ data from the field or gathering experimental data, modeling the process with different approaches, and performing case studies from Europe and the Mediterranean North Africa to typhoon-dominated Asia and even to polar Antarctica. The Special Issue therefore represents highly diverse research activities.

A summary of the papers in the Special Issue follows, given in the order in which they appear.

The grain size distribution of bedload transported within a given water discharge has been investigated for two polar catchments in Antarctica [45], aimed at determining how the grain size distribution is modified during times of peak discharge, determining the relationship between the grain size distribution and its parameters, and the amount of transported material in gravel-bed rivers, and examining whether the modification of grain size distribution during efficient bedload transport events allow for the identification of the development stage of river throughs during changing 
meteorological conditions. These questions were answered after a measurement campaign in two creeks with proglacial gravel-bed channels. At the end it is confirmed that the variability and modification of grain size distributions are strongly related to the daily variability of bedload transport dynamics. The increased proportion of medium and coarse gravel was strictly proportional to the increase in water discharge. An efficient erosive process, which is confirmed by the general conditions of both streams, is significantly influenced by bedload transport.

Urban sewer conduits prevent flooding in urban areas by discharging runoff generated during rainfall. With an improper design of urban sewer conduits, severe soil sedimentation can occur in the conduits which threatens the capacity and ability of the system to discharge the flood during the rainy season or at localized heavy rainfalls. Soil slurry deposited on the surface of the Earth during rainfall that flows into urban sewer conduits was investigated [46] to propose a functional relationship between critical tractive force in urban sewer conduits and the physical properties of particles in a conduit bed which are taken as the inlet flow velocity of the soil slurry mixture, the volume concentration of the soil, and its particle size. For the two-phase soil slurry flow, a numerical analysis was performed based on various flow conditions to conclude that the findings of this study may be helpful to prevent conduit clogging or conduit damage that may occur during heavy rainfall events. As this study considered only the inflow of a large amount of soil slurry at the beginning of rainfall events, it is open for further investigation to introduce various types of rainfall events by using data from real conduit systems.

Algeria, in northern Africa, has always been confronted with severe periodic droughts as well as catastrophic floods, both being major constraints against the economic and social development of the country [47]. In order to combat both natural hazards, the total number of dams increased quite quickly, from 14 in 1962 to 65 in 2014. The scale of aggradations and the raising of the bottom of these dam impoundments by successive deposits of sediments-brought by the watercourses and the wind-are serious problems whose negative consequences are considerably felt in the agriculture, farming, fishing, electricity, and navigation fields. The sedimentation in North African dams is very high in relation to what is noted in the watershed of Wadi Mina in semiarid northwest Algeria, and it has been the subject of the study of Hallouz et al. [47]. Also, with a trend starting in the late 1980s, the annual production of sediment became seven times larger than the previous period, with a four times greater increase in the rates of contribution in the dry season. By comparing the results, it is observed that the upstream basin is the greatest sediment producer towards the dam.

The Mediterranean Maghreb Basin (MMB), that extends over Morocco, Algeria, and Tunisia, is a region where both mechanical erosion rates and the anthropogenic pressure on surface water resources are high and were subject to analysis [48]. Based on sediment trapping, calculated by the models using information and limited data from 470 out of 670 reservoirs in the area, it is confirmed that natural sediment yields are clearly above the world average, with the largest being in Morocco and the smallest in Tunisia. Trapping rates have an opposite order, being the highest in the Tunisian part of the basin, followed by the Algerian and the Moroccan parts. Trapping of the sediment in their reservoirs greatly reduces the natural sediment flux of the dams in the entire Mediterranean Maghreb Basin to the sea; only slightly more than one-third of the natural river sediment fluxes reaches the coastal Mediterranean waters of the Maghreb [49,50]. The effect of small reservoirs and hillside reservoirs should not be ignored in the interception of sediment compared to large reservoirs, although they have shorter life spans than large reservoirs, and their economic exploitation is limited in time. Understanding the impact of dams and related water infrastructures on riverine sediment dynamics is key in arid zones such as the Mediterranean Maghreb Basin, where global warming is predicted to cause important changes in the climatic conditions and the water availability.

Small-scale laboratory rainfall simulator experimental data based on high-precision DEM are evaluated to provide accurate, but affordable, soil loss estimates [51]. Laser-scanned topography and sediment yields were collected every $5 \mathrm{~min}$ in each test. The difference between the DEMs from laser scans of different time steps gives the eroded soil volumes and the corresponding estimates of soil loss in mass. It is seen that sediment yield and eroded soil volume increased with rainfall duration and 
slope. It is demonstrated that the stripe laser-scanning method is applicable in soil loss prediction and erosion evaluation in laboratory case studies, and could be taken for further case studies of larger scales such that a method that is useful, in practice, can be generated.

Climate change and human activities are two major factors affecting runoff and sediment load in hydrological basins [52]. Gradual or sudden changes in hydrometeorological characteristics, such as annual rainfall, air temperature, runoff, and sediment load, are important in simulating the watershed hydrological cycle. These gradual and sudden changes are mainly linked to the contributions of climate change and human activities to runoff and sediment load under change. Results showed that both rainfall and air temperature increased whilst runoff and sediment load decreased. The air temperature experienced a sudden increase and sediment load decrease in 1988. Soil erosion was found to be worse in the upper part of the basin than other parts, and it is the highest in cultivated land. Climate change exacerbates runoff and sediment load with overall contribution to the total change while, on the other hand, human activities decreased runoff and sediment load with overall contribution to the total change. The conclusion of the study is that the variation of runoff and sediment load in the Xihe River Basin in China is largely caused by human activities.

Soil, hillslopes, and watercourses in small catchments possess a degree of natural attenuation that affects both the shape of the outlet hydrograph and the transport of nutrients and sediments [53]. The headwaters of such catchments are expected to add additional attenuation primarily through increasing the amount of new storage available to accommodate flood flows. The actual types of so-called natural-based solutions include swales, ditches, and small ponds (acting as sediment traps). A modeling study was performed on a small subcatchment of $1.25 \mathrm{~km}^{2}$ in order to address the impacts of land management by altering hydrological flow paths and the overall catchment attenuation capacity on flow rates and nutrient losses. The model results implied that a small decrease in the order of $5 \%-10 \%$ in the peak concentrations of suspended sediment and nutrients was observed with an increase in the catchment storage.

An indoor laboratory-scale experimental study is quite beneficial to the sediment transport problem as the urban drainage and sewer systems are final reaching points for any type of sediment to be washed into the channels or conduits [54]. Using the self-cleansing concept, different cross-section channels were tested to better clarify the fuzziness between the incipient deposition and incipient motion of sediment particles moving within the flow. With this aim, an experimental study carried out in trapezoidal, rectangular, circular, U-shape, and V-bottom channels for four different sizes of sand as the sediment in the experiments was performed in a tilting flume under nine different longitudinal channel bed slopes. The shear stress approach was considered for the analysis in which the well-known Shields and Yalin methods were used. The circular channel was found to be the second most efficient after the rectangular channel, and the V-bottom channel the least in transporting sediment within the drainage system. The outputs of this study are expected to be useful for practical use in the design of urban drainage and sewer systems that collect the sediment load together with nutrients.

Extreme weather phenomena which have been a part of daily hydrometeorological practice worldwide bring catastrophic disasters under the impact of climate change; and Taiwan has no exemption, due to an increase in the frequency of extreme rainfall events [55]. Extreme rainfall events might cause riverbed migrations, such as degradation and aggradation. The extrapolation of typhoon events-observed in the past by the CCHE1D model—under the climate change scenario of representative concentration pathways 8.5 (RCP8.5) and dynamical downscaling of rainfall data in Taiwan shows that the average peak flow during extreme rainfall events will increase by $20 \%$ relative to the base period, but the time required to reach the peak will be $8 \mathrm{~h}$ shorter than that in the base period. It is expected that the aggradation of the riverbed will increase by the end of the 21st century. It is also foreseen that anthropogenic activities, such as blocking upstream sediment by structures such as a weir, will clearly increase the severity of scouring downstream. The study finally indicates that not only will larger floods occur within a shorter time duration, but that the catchment will also face more severe degradation and aggradation in the future. 
In addition to sand-dominated sediment being transported within flow, gravel may also be transported in rivers with mixed-size bed material when dealing with large rivers with complex hydrodynamics and morphodynamics [56]. This is the collapse of the uniform sediment assumption, which then requires a suitable approach to estimate the nonuniform behavior of the sediment transport. Utilizing the shear Reynolds number, a decision criterion which is based on the combined use of several formulas, each of them having a certain application range, was verified with the field and laboratory data of nonuniform bed material compositions. The proposed approach is able to predict domination of sand or gravel transport with an uncertainty of less than $5 \%$.

In central Czech Republic, a small stream catchment with an agricultural and forest-agricultural landscape and relatively rugged topography and riverbed slope [57] make the terrain very vulnerable to water erosion, and this was studied to compare four selected soil erosion and sediment delivery models-WaTEM/SEDEM, USPED, InVEST, and TerrSet, with each working on several different algorithms. The models were compared based on the total volume of eroded and accumulated sediment within the catchment per unit time, and according to the spatial distribution of sites susceptible to soil loss or sediment accumulation. Despite the fact that the models are different in terms of calculation algorithms and data preprocessing requirements, comparable results in calculating the average annual soil loss and accumulation were obtained but they behaved differently in identifying the spatial distribution of specific locations prone to soil loss or accumulation processes.

\section{Establishment of the Special Issue}

Scope and coverage: When the Special Issue had been scheduled, it was anticipated to be a collection of contributions focusing on erosion and sediment transport issues in riverbeds or watersheds using analytical, numerical, and in situ experimental tools. However, laboratory experiments were also found to be an important consideration, due to their providing specific details in the transport of sediment.

Scale: Another point is the scale issue, that has varied greatly among the papers published in the Special Issue. The erosion and sediment transport issues have been investigated in channels and over watersheds. The channels have been either a prototype natural watercourse $[45,54]$ or an artificial flume of a laboratory model $[46,54]$. As for the watersheds, the scale has changed from $1.25 \mathrm{~km}^{2}$ subcatchments from the United Kingdom [53] to large, millions of $\mathrm{km}^{2}$ watersheds in the Maghrib basin that extend over Morocco, Algeria, and Tunisia.

Geographical diversity: The Special Issue has not been a collection of studies concentrated on a specific region. The papers have large geographical variability, from the Maghrib area in North Africa to typhoon-dominated Taiwan and even Antarctica. Therefore, the erosion and sediment transport problem has not been limited to a particular region but extends over a geographical scale representing large diversity.

Large rivers vs. small rivers: Large rivers carry not only sand-type sediment but also gravel-dominated bedload which contradict with the uniform-size sediment assumption. However, in smaller rivers, the assumption that the sediment has a uniform grain size could be considered valid to a certain degree. In this sense, it is important that bedload sediment models should be dealt with differently when one is interested in a large river where the bedload is gravel-dominated and, thus, no uniformity exists in terms of sediment size.

In situ measurements and laboratory data: It is important that any model is validated with real data, which is a headache for all scientists and practitioners who deal with Earth sciences. Hydrology is no exception, and erosion and sediment transport are particular issues which experiences this problem at the highest level, due to the fact that sediment data are not collected as frequently as other hydrometeorological variables, such as precipitation, evaporation, humidity, streamflow, etc. Therefore, in situ problem-specific data collection efforts are quite valuable. Laboratory studies could also be as useful as fields studies. This is a fact that has been touched upon; the former could be replaced by the latter when it is hard to perform field studies and when the latter is possible. 
Climate change and anthropogenic activities: It is an inevitable reality that hydrology is under change that is either linked to the climatology or Anthropocene. More frequent floods with higher peaks are reached in shorter time intervals than before. This is a challenge that can be associated with the stationary time series methodologies. The stationarity is now dead, and the past is no longer the mirror for the future as it was before.

\section{Conclusions}

The Special Issue has attracted the interest of hydrologists and water resources researchers. It is a common belief of the authors of this Editorial that all papers in this Special Issue could be considered a contribution to the erosion and sediment transport problem in hydrological watersheds at different scales of space and time and also under any kind of change.

Author Contributions: Conceptualization, G.M., H.A., M.M.; Writing-Original Draft Preparation, H.A.; Writing-Review \& Editing, H.A., G.M., M.M.

Funding: This research received no external funding.

Acknowledgments: The authors thank editors for their help during the processes for the Special Issue. Yonca Cavus, PhD candidate from Istanbul Technical University, read the draft and edited it carefully. The authors are thankful to her for the time she dedicated to this Editorial.

Conflicts of Interest: The authors declare no conflict of interest.

\section{References}

1. Foster, G.R.; Meyer, L.D. A Closed-Form Soil Erosion Equation for Upland Areas. In Sedimentation Symposium in Honor Prof. H.A. Einstein; Shen, H.W., Ed.; Colorado State University: Fort Collins, CO, USA, 1972; pp. 12.1-12.19.

2. Prowse, T.D. Suspended sediment concentration during breakup. Can. J. Civ. Eng. 1993, 20, 872-875. [CrossRef]

3. Costar, F.; Dupeyrat, L.; Gautier, E.; Carey-Gailhardis, E. Fluvial thermal erosion investigations along a rapidly eroding river bank: Applications to the Lena River (Central Siberia). Earth Surf. Process. Landf. 2003, 28, 1349-1359. [CrossRef]

4. Knack, I.M.; Shen, H.T. A numerical model for sediment transport and bed change with river ice. J. Hydraul. Res. 2018, 56, 844-856. [CrossRef]

5. Burrell, B.C.; Beltaos, S. Effects and implications of river ice breakup on suspended-sediment concentrations: A synthesis. In Proceedings of the CGU HS Committee on River Ice Processes and the Environment 20th Workshop on the Hydraulics of Ice-Covered Rivers, Ottawa, ON, Canada, 14-16 May 2019.

6. ASCE Task Committee. Sediment sources and sediment yields. ASCEJ. Hydraul. Div. 1970, 96, 1283-1329.

7. Kuznetsov, M.S.; Gendugov, V.M.; Khalilov, M.S.; Ivanuta, A.A. An equation of soil detachment by flow. Soil Tillage Res. 1998, 46, 97-102. [CrossRef]

8. Emmett, W.W. The Hydraulics of Overland Flow on Hillslopes; USGS (United States Geological Survey): Washington, DC, USA, 1970; Volume 662A, 68p.

9. Bennett, J.P. Concepts of mathematical modeling of sediment yield. Water Resour. Res. 1974, 10, 485-492. [CrossRef]

10. Croley, I.I. TE Unsteady overland sedimentation. J. Hydrol. 1982, 56, 325-346. [CrossRef]

11. Phien, H.N.; Arbhabhirama, A. A statistical analysis of the sediment accumulation in reservoirs. J. Hydrol. 1979, 44, 231-240. [CrossRef]

12. Skoklevski, Z.; Velickov, S. Suspended load transportation process within Vardar river basin in the Republic of Macedonia. In Proceedings of the XIXth conference Danube Countries on the Hydrological Forecasting and Hydrological Bases of Water Management, Osijek, Croatia, 15-19 June 1998; pp. 717-727.

13. Tingsanchali, T.; Lal, N.K. A combined deterministic-stochastic model of daily sediment concentrations in a river. In Proceedings of the Sixth IAHR International Symposium Stochastic Hydraulics, Taipei, Taiwan, 18-20 May 1992; pp. 221-228.

14. Rosen, T.; Xu, Y.J. A hydrograph-based sediment availability assessment: Implications for Mississippi River sediment diversion. Water 2014, 6, 564-583. [CrossRef] 
15. Bogardi, J. Sediment Transport in Alluvial Streams; Akademiai Kiado: Budapest, Hungary, 1974.

16. Box, G.E.P.; Jenkins, G.M.; Reinsel, G.C. Time Series Analysis, Forecasting and Control; Prentice-Hall: Englewood Cliffs, NJ, USA, 1994.

17. Szidarovszky, F.; Yakowitz, S.; Krzysztofowicz, R. A Bayes approach for simulating sediment yield. J. Hydrol. Sci. 1976, 3, 33-44.

18. Phien, H.N. Reservoir sedimentation with correlated inflows. J. Hydrol. 1981, 53, 327-341. [CrossRef]

19. Aksoy, H.; Akar, T.; Unal, N.E. Wavelet analysis for modeling suspended sediment discharge. Nord. Hydrol. 2004, 35, 165-174. [CrossRef]

20. Hao, C.F.; Qiu, J.; Li, F.F. Methodology for analyzing and predicting the runoff and sediment into a reservoir. Water 2017, 9, 440. [CrossRef]

21. Garde, R.J.; Ranga Raju, K.G. Mechanics of Sediment Transportation and Alluvial Stream Problems; Wiley Eastern: New Delhi, India, 1977.

22. Tfwala, S.S.; Wang, Y.M. Estimating sediment discharge using sediment rating curves and artificial neural networks in the Shiwen River, Taiwan. Water 2016, 8, 53. [CrossRef]

23. Araujo, J.C.; Güntner, A.; Bronstert, A. Loss of reservoir volume by sediment deposition and its impact on water availability in semiarid Brazil. Hydrol. Sci. J. 2006, 51, 157-170. [CrossRef]

24. Baban, S.M.J.; Yusof, K.W. Modeling soil erosion in tropical environments using remote sensing and geographical information systems. Hydrol. Sci. J. 2001, 46, 191-198. [CrossRef]

25. Wicks, J.M. Physically-Based Mathematical Modelling of Catchment Sediment Yield. Ph.D. Thesis, Department of Civil Engineering, University of Newcastle Upon Tyne, Tyne, UK, 1988.

26. Nearing, M.A.; Foster, G.R.; Lane, L.J.; Finkner, S.C. A process-based soil erosion model for USDA-water erosion prediction project technology. Trans. ASAE 1989, 32, 1587-1593. [CrossRef]

27. Ayele, G.T.; Teshale, E.Z.; Yu, B.; Rutherfurd, I.D.; Jeong, J. Streamflow and sediment yield prediction for watershed prioritization in the Upper Blue Nile river basin, Ethiopia. Water 2017, 9, 782. [CrossRef]

28. Kavvas, M.L.; Chen, Z.Q.; Dogrul, C.; Yoon, J.Y.; Ohara, N.; Liang, L.; Aksoy, H.; Anderson, M.L.; Yoshitani, J.; Fukami, K.; et al. Watershed environmental hydrology (WEHY) model based on upscaled conservation equations: Hydrologic module. ASCE J. Hydrol. Eng. 2004, 9, 450-464. [CrossRef]

29. Kavvas, M.L.; Yoon, J.Y.; Chen, Z.Q.; Liang, L.; Dogrul, C.; Ohara, N.; Aksoy, H.; Anderson, M.L.; Reuter, J.; Hackley, S. Watershed environmental hydrology model: Environmental module and its application to a California watershed. ASCE J. Hydrol. Eng. 2006, 11, 261-272. [CrossRef]

30. Aksoy, H.; Kavvas, M.L. A review of hillslope and watershed scale erosion and sediment transport models. Catena 2005, 64, 247-271. [CrossRef]

31. Merritt, W.S.; Letcher, R.A.; Jakeman, A.J. A review of erosion and sediment transport models. Environ. Model. Softw. 2003, 18, 761-799. [CrossRef]

32. Milly, P.C.D.; Betancourt, J.; Falkenmark, M.; Hirsch, R.M.; Kundzewicz, Z.W.; Lettenmaier, D.P.; Stouffer, R.J. Stationarity is dead: Whither water management? Science 2008, 319, 573-574. [CrossRef]

33. Montanari, A.; Young, G.; Savenije, H.H.G.; Hughes, D.; Wagener, T.; Ren, L.L.; Koutsoyiannis, D.; Cudennec, C.; Toth, E.; Grimaldi, S.; et al. Panta Rhei-Everything Flows: Change in hydrology and society-The IAHS Scientific Decade 2013-2022. Hydrol. Sci. J. 2013, 58, 1256-1275. [CrossRef]

34. McMillan, H.; Montanari, A.; Cudennec, C.; Savenjie, H.; Kreibich, H.; Krüger, T.; Liu, J.; Meija, A.; van Loon, A.; Aksoy, H.; et al. PantaRhei 2013-2015: Global perspectives on hydrology, society and change. Hydrol. Sci. J. 2016, 61, 1174-1191. [CrossRef]

35. Ceola, S.; Montanari, A.; Krueger, T.; Dyer, F.; Kreibich, H.; Westerberg, I.; Carr, G.; Cudennec, C.; Elshorbagy, A.; Savenije, H.; et al. Adaptation of water resources systems to changing society and environment: A statement by the International Association of Hydrological Sciences. Hydrol. Sci. J. 2016, 61, 2803-2817. [CrossRef]

36. Bu, J.; Lu, C.; Niu, J.; Gao, Y. Attribution of runoff reduction in the Juma River basin to climate variation, direct human intervention, and land use change. Water 2018, 10, 1775. [CrossRef]

37. Koutsoyiannis, D. Hurst-Kolmogorov dynamics and uncertainty. J. Am. Water Resour. Assoc. 2011, 47, 481-495. [CrossRef]

38. Lins, H.F.; Cohn, T.A. Stationarity: Wanted dead or alive? J. Am. Water Resour. Assoc. 2011, 47, 475-480. [CrossRef] 
39. Matalas, N.C. Comment on the announced death of stationarity. J. Water Resour. Plann. Manag. 2012, 138, 311-312. [CrossRef]

40. Koutsoyiannis, D.; Montanari, A. Negligent killing of scientific concepts: The stationarity case. Hydrol. Sci. J. 2015, 60, 1174-1183. [CrossRef]

41. Grimaldi, S.; Kao, S.-C.; Castellarin, A.; Papalexiou, S.-M.; Viglione, A.; Laio, F.; Aksoy, H.; Gedikli, A. Statistical Hydrology, Treatise on Water Science; Wilderer, P., Ed.; Academic Press: Oxford, UK, 2011; Volume 2, pp. 479-517.

42. Gedikli, A.; Aksoy, H.; Unal, N.E. Segmentation algorithm for long time series analysis. Stoch. Environ. Res. Risk Assess. 2007, 22, 291-302. [CrossRef]

43. Aksoy, H.; Gedikli, A.; Unal, N.E.; Kehagias, A. Fast segmentation algorithms for long hydrometeorological time series. Hydrol. Process. 2008, 22, 4600-4608. [CrossRef]

44. Gedikli, A.; Aksoy, H.; Unal, N.E.; Kehagias, A. Modified dynamic programming approach for offline segmentation of long hydrometeorological time series. Stoch. Environ. Res. Risk Assess. 2010, 24, 547-557. [CrossRef]

45. Szilo, J.; Bialik, R.J. Grain size distribution of bedload transport in a gliaciated catchment (Baranowski Glacier, King George Island, Western Antartctica). Water 2018, 10, 360. [CrossRef]

46. Song, Y.H.; Lee, E.H.; Lee, J.H. Functional relationship between soil slurry transfer and deposition in urban sewer conduits. Water 2018, 10, 825. [CrossRef]

47. Hallouz, F.; Meddi, M.; Mahe, G.; Toumi, S.; Rahmani, S.E.A. Erosion, suspended sediment transport and sedimentation on the Wadi Mina at the Sidi M'Hamed Ben Aouda Dam, Algeria. Water 2018, 10, 895. [CrossRef]

48. Sadaoui, M.; Ludwig, W.; Bourrin, F.; Bissonnais, Y.L.; Romero, E. Anthropogenic reservoirs of various sizes trap most of the sediment in the Mediterranean Maghreb Basin. Water 2018, 10, 927. [CrossRef]

49. Kotti, F.; Dezileau, L.; Mahe, G.; Habaieb, H.; Benabdallah, S.; Bentkaya, M.; Calvez, R.; Dieulin, C. The impact of dams and climate on the evolution of the sediment loads to the sea by the Medjerda River using a paleo-hydrological approach. J. Afr. Earth. Sci. 2018, 142, 226-233. [CrossRef]

50. Ben Moussa, T.; Amrouni, O.; Hzami, A.; Dezileau, L.; Mahe, G.; Condomines, M.; Saadi, A. Progradation and retrogradation of the Medjerda delta during the 20th century (Tunisia, Western Mediterranean). Compte. Rendus Geosci. 2019, 351, 340-350. [CrossRef]

51. Wang, Y.-C.; Lai, C.-C. Evaluating the erosion process from a single-stripe laser-scanned topography: A laboratory case study. Water 2018, 10, 956. [CrossRef]

52. Guo, S.; Zhu, Z.; Lyu, L. Effects of climate change and human activities on soil erosion in the Xihe River Basin, China. Water 2018, 10, 1085. [CrossRef]

53. Adams, R.; Quinn, P.; Barber, N.; Reaney, S. The role of attenuation and land management in small catchments to remove sediment and phosphorus: A modelling study of mitigation options and impacts. Water 2018, 10, 1227. [CrossRef]

54. Unal, N.E. Shear stress-based analysis of sediment incipient deposition in rigid boundary open channels. Water 2018, 10, 1399. [CrossRef]

55. Chao, Y.-C.; Chen, C.-W.; Li, H.-C.; Chen, Y.-M. Riverbed migrations in Western Taiwan under climate change. Water 2018, 10, 1631. [CrossRef]

56. Török, G.T.; Józsa, J.; Baranya, S. A shear Reynolds number-based classification method of the nonuniform bed load transport. Water 2019, 11, 73. [CrossRef]

57. Jakubínský, J.; Pechanec, V.; Procházka, J.; Cudlín, P. Modelling of soil erosion and accumulation in an agricultural landscape-A comparison of selected approaches applied at the small stream basin level in the Czech Republic. Water 2019, 11, 404. [CrossRef]

(C) 2019 by the authors. Licensee MDPI, Basel, Switzerland. This article is an open access article distributed under the terms and conditions of the Creative Commons Attribution (CC BY) license (http://creativecommons.org/licenses/by/4.0/). 